\title{
Opsonic Activity, Phagocytosis, and Bactericidal Capacity of Polymorphs in Undernutrition
}

\author{
V. SETH and R. K. CHANDRA \\ From the Department of Paediatrics, All India Institute of Medical Sciences, New Delhi, India
}

Seth, V., and Chandra, R. K. (1972). Archives of Disease in Childhood, 47, 282. Opsonic activity, phagocytosis, and bactericidal capacity of polymorphs in undernutrition. Fifteen undernourished infants and children were studied for opsonic activity of plasma, and for phagocytosis and intracellular bactericidal capacity of polymorphonuclear leucocytes. The opsonic activity was slightly increased and there was a significant decrease in bacterial killing by polymorphs of malnourished individuals compared with healthy controls. Phagocytosis was comparable in the 2 groups. In 3 patients, the impairment of bacterial killing was reversed to normal on recovery from nutritional deficit. It is suggested that this may be one possible mechanism of infection-nutrition interaction.

Clinical observations suggest that malnutrition increases the susceptibility to and severity of disease caused by bacteria, viruses, parasites, and other pathogens, and that infections have an adverse effect on the nutritional state (Scrimshaw, Taylor and Gordon, 1968). Previous reports suggest that defects of antibody response (Hodges et al., 1962), specific cell-mediated response (Harland, 1965), serum transferrin (Antia, McFarlane, and Soothill, 1968), skin (Trowell, Davies, and Dean, 1954), and gut (Ramalingaswami and Deo, 1968), for example, may all contribute to this. Infective organisms in malnourished children include Grampositive cocci, in immunity to which polymorphs play an important role, but no studies of polymorph function in undernutrition have been reported. We therefore conducted an in vitro study of the phagocytic and bactericidal functions of polymorphs and opsonic activity of plasma obtained from undernourished infants and children.

\section{Material and Methods}

Fifteen children, aged 1 to 5 years, who came to the outpatient department with failure to thrive, in whom dietary history indicated inadequate intake of calories and proteins, and who were below the 10th centile on charts for healthy subjects in the same community (Ghai and Sandhu, 1968), were studied. All the cases showed loss of subcutaneous fat, hair and skin changes, and anaemia. Two showed, in addition, the presence of oedema and vitamin A deficiency.

Received 4 October 1971.
Healthy adults and children served as controls. Our observations indicate that apart from the immediate postnatal period, the polymorph functions evaluated in this study are not age-dependent.

The bactericidal test, essentially as described by Quie et al. (1967), using Staphylococcus aureus and surface counting of colonies on nutrient agar plates, was used to measure opsonin (antibody, complement, etc.) function of plasma, and phagocytosis and bacterial killing by polymorphs. The opsonic activity was estimated by the number of bacteria phagocytosed by polymorphs of healthy controls at 20 minutes of culture in the presence of $10 \%$ plasma from the patient or from the control (whose polymorphs were used). The bactericidal capacity of the polymorphs was calculated by the ratio: number of viable intracellular bacteria at 140 minutes/number at 20 minutes of the culture, using the control plasma in the culture medium.

\section{Results}

The results are shown in Table I. The geometric means of the bactericidal capacity of polymorphs from the 2 groups were significantly different $(t=6.3, P<0.001)$, the cells from undernourished children being less efficient. There was, however, some overlap of values obtained in individual patients and controls. In view of the considerable day-to-day variations of such techniques, we also analysed the ratio of bactericidal capacity of patients' cells versus the control of the same day. The mean of these ratios was found to be significantly greater than one $(t=$ $2 \cdot 65, \mathrm{P}<0 \cdot 05)$. 
TABLE I

Range and Geometric Mean Values of Opsonic Activity of Plasma, Phagocytosis, and Intracellular Bacterial Killing by Polymorphs in Patients and Controls

\begin{tabular}{|c|c|c|c|c|c|c|c|c|c|}
\hline & \multicolumn{3}{|c|}{$\begin{array}{l}\text { No. of Viable Intracellular Bacteria at } \\
20 \mathrm{Min} \text { in Polys from Controls per } \\
\mathrm{ml} \text { of Culture Mixture }\end{array}$} & \multicolumn{3}{|c|}{$\begin{array}{l}\text { No. of Viable Intracellular Bacteria at } \\
20 \text { Min Using Plasma from Controls }\end{array}$} & \multicolumn{3}{|c|}{$\begin{array}{c}\text { No. of Viable Intracellular Bacteria at } \\
140 \text { Min/No. at } 20 \text { Min of Culture } \\
\text { Using Control Plasma }\end{array}$} \\
\hline Range & $\begin{array}{l}10 \times 10^{3} \\
\text { to } \\
14 \times 10^{4}\end{array}$ & $\begin{array}{l}75 \times 10^{2} \\
\text { to } \\
17 \times 10^{4}\end{array}$ & $\begin{array}{l}12 \cdot 5 \\
\text { to } \\
0 \cdot 6\end{array}$ & $\begin{array}{l}7 \times 10^{3} \\
\text { to } \\
21 \times 10^{4}\end{array}$ & $\begin{array}{l}75 \times 10^{2} \\
\text { to } \\
38 \times 10^{4}\end{array}$ & $\begin{array}{l}2 \cdot 80 \\
\text { to } \\
0 \cdot 90\end{array}$ & $\begin{array}{l}0 \cdot 10 \\
\text { to } \\
1 \cdot 00\end{array}$ & $\begin{array}{l}0.02 \\
\text { to } \\
0 \cdot 37\end{array}$ & $\begin{array}{c}10 \cdot 00 \\
\text { to } \\
0 \cdot 81\end{array}$ \\
\hline Mean & $45 \times 10^{3}$ & $11 \times 10^{3}$ & $2 \cdot 8$ & $41 \times 10^{3}$ & $27 \times 10^{3}$ & $1 \cdot 37$ & 0.41 & 0.07 & $3 \cdot 10$ \\
\hline
\end{tabular}

In 3 patients recovery from malnutrition in 4 to 6 weeks was associated with a reversal of the bactericidal abnormality of polymorphs (Table II).

The opsonic activity of plasma from the patients was slightly greater than that of plasma from the controls $(t=1.98,0.1>P>0.05)$. This was done on 10 sequential patients who were not selected in any other manner.

TABLE II

Intracellular Bacterial Killing by Polymorphs, Before and After Correction of Undernutrition

\begin{tabular}{|c|c|c|c|}
\hline \multirow{2}{*}{ Case No. } & \multicolumn{3}{|c|}{$\begin{array}{l}\text { Viable Intracellular Bacteria at } \\
140 \text { Minutes } / 20 \text { Minutes of Culture }\end{array}$} \\
\hline & Patient & Control & Patient/Control \\
\hline $\begin{array}{l}\text { (1) Before therapy } \\
\text { After therapy } \\
\text { (2) Before therapy } \\
\text { After therapy } \\
\text { (3) Before therapy } \\
\text { After therapy }\end{array}$ & $\begin{array}{l}0 \cdot 37 \\
0 \cdot 07 \\
0 \cdot 22 \\
0 \cdot 14 \\
1 \cdot 10 \\
0 \cdot 22\end{array}$ & $\begin{array}{l}0 \cdot 05 \\
0 \cdot 13 \\
0 \cdot 08 \\
0 \cdot 16 \\
0.08 \\
0.08\end{array}$ & $\begin{array}{r}7 \cdot 40 \\
0 \cdot 54 \\
2 \cdot 80 \\
0 \cdot 87 \\
13 \cdot 70 \\
2 \cdot 70\end{array}$ \\
\hline
\end{tabular}

The mean uptake of bacteria was not significantly different in the 2 groups $(t=0.09 \mathrm{P}>0 \cdot 1)$.

\section{Discussion}

In defence against invading micro-organisms, the host musters a number of protective mechanisms (Humphrey and White, 1970). Bacterial infections elicit leucocytosis possibly through immediate release of cells from sites of sequestration and later through increased production, chemotaxis, and migration of microphages and macrophages, which engulf the invaders, a process in which opsonins (antibodies, complement, and perhaps other proteins) may play a significant role. Phagocytosis activates intracellular metabolic processes and killing takes place. This step of intracellular digestion of bacteria has received increasing attention recently through studies on patients with chronic granulomatous disease. The key role played by lysosomal granules has come to light (Nathan, Weaver, and Baehner, 1969). There are at least 4 possible mechanisms for killing organisms inside the cells: (1) the lysosomal 'phagocytin' system involving arginine-rich cationic proteins; (2) the hydrogen peroxide system; (3) muramidase activity; and (4) the hydrolases.

Our data show that intracellular bacterial digestion by polymorphs of undernourished children is impaired. Since lysosomal precursors are amino acids, a situation where there is a paucity of proteins, as in malnutrition, may impair the synthesis of lysosomal enzymes in normal amounts. Other activities of the cell involving protein turnover, such as division and cell replacement, are known to be severely affected in experimental primate malnutrition (Ramalingaswami and Deo, 1968) and in its clinical counterparts.

Infections in malnourished subjects vary greatly in their severity and the type of organisms involved. Occasionally, Gram-positive cocci may be responsible for multiple abscesses in sites such as the lungs, bones, brain, lymph nodes, and skin, a picture resembling clinical manifestations of chronic granulomatous disease, in which the basic defect lies in the inability of polymorphs to deal effectively with intracellular bacteria, especially Gram-positive cocci, and some fungi. However, undernutrition also increases the susceptibility to viruses and other bacteria which do not seem to affect patients with chronic granulomatous disease in any unusual way. It seems, therefore, that though intracellular killing by polymorphs is defective in malnutrition, the degree of impairment is not so marked in the majority as to produce clinical manifestations resembling chronic granulomatous disease. The reversal of polymorph defect after therapeutic feeding for a few weeks, seen in 3 patients, shows 
that the abnormality in killing was indeed due to undernutrition.

Our data indicate that the ingestion of bacteria by polymorphs is slightly facilitated by plasma from undernourished subjects compared with control plasma. This opsonic function is dependent upon antibodies, complement, and perhaps other serum factors. Complement is generally low in children with malnutrition (R. K. Chandra, in preparation), and the increased opsonic activity of plasma may be due to the presence of specific antibodies to the test organism produced as a result of previous exposure, or to some other factor. There is no proof for any of these explanations yet. In acutely starved animals, Saba and DiLuzio (1968) detected deranged opsonic activity which significantly impaired the functional activity of the reticuloendothelial system.

Phagocytosis was comparable in the undernourished and control groups. This confirms the observations of Balch and Spencer (1954) who studied phagocytosis by visual counting of the number of bacteria ingested by polymorphs and did not find any difference between healthy and malnourished individuals.

The increased susceptibility to infections in undernourished children may also depend upon defects in other aspects of immunity function. There are several reports of reduced antibody formation following antigenic challenge in starved hypoproteinaemic animals (Cannon, 1945). The data in man are controversial; some reports show a reduction in antibody response (Hodges et al., 1962), whereas others find it adequate (Pretorius and De Villiers, 1962). Our own observations (R. K. Chandra, in preparation) indicate that malnourished children may have either hyperimmunoglobulinaemia or hypoimmunoglobulinaemia $\mathrm{G}$, depending upon the presence or absence of infection or a recent history of it. Such subjects exhibit a good response to toxoid antigens but a relatively poor performance after injection of particulate material such as Salm. typhi. It has also been shown that specific cell mediated immunity is impaired in undernutrition (Harland, 1965) and that serum siderophilin, which has an antibacterial role to play, is low in kwashiorkor (Antia et al., 1968). It is likely that all the above-mentioned factors contribute to the increased frequency and severity of infections in undernourished infants and children.

We are grateful to the Indian Council of Medical $\frac{\bar{S}}{\vec{D}}$ Research for the award of a postdoctoral fellowship to $\varrho$ one of us (V.S.). We thank Professor O. P. Ghai for constant encouragement and permission to publish this paper, and Mr. Shiv Prasad for technical assistance.

\section{REFERENCES}

Antia, A. U., McFarlane, H., and Soothill, J. F. (1968). Serum siderophilin in kwashiorkor. Archives of Disease in Childhood, 43, 459.

Balch, H. H., and Spencer, M. T. (1954). Phagocytosis by human if leucocytes. II. Relation of nutritional deficiency in man to phagocytosis. Fournal of Clinical Investigation, 33, 1321.

Cannon, P. R. (1945). The importance of proteins in resistance to $\mathrm{N}$ infection. Fournal of the American Medical Association, 128, N 360.

Ghai, O. P., and Sandhu, R. K. (1968). Study of physical growth of Indian children in Delhi. Indian fournal of Pediatrics, 35, 윽 91.

Harland, P. S. E. G. (1965). Tuberculin reactions in malnourished children. Lancet, 2, 719.

Hodges, R. E., Bean, W. B., Ohlson, M. A., and Bleiler, R. E. (1962). 을 Factors affecting human antibody response. American fournal of Clinical Nutrition, 10, 500.

Humphrey, J. H., and White, R. G. R. (1970). Immunology for $N$ Students of Medicine, 39, 86. Blackwell, Oxford.

Nathan, D. G., Weaver, D. K., and Baehner, R. K. (1969). Chronic granulomatous disease. In Enzymopenic Anaemias, Lysosomes and Other Papers, p. 61. Ed. by J. D. Allan, K. S. Holt, J. T. Ireland, and R. J. Pollitt. Livingstone, Edinburgh.

Pretorius, P. J., and De Villiers, L. S. (1962). Antibody response in children with protein malnutrition. American fournal of Clinical Nutrition, 10, 379.

Quie, P. G., White, J. G., Holmes, B. W., and Good, R. A. (1967). In vitro bactericidal capacity of human polymorphonuclear $\overline{\mathrm{O}}$ leukocytes: diminished activity in chronic granulomatous 3 disease of childhood. Fournal of Clinical Investigation, 46, 668.

Ramalingaswami, V., and Deo, M. G. (1968). Experimental protein-calorie malnutrition in the Rhesus monkey. In? Calorie Deficiencies and Protein Deficiencies, p. 265 . Ed. by R. A. McCance and E. M. Widdowson. Churchill, London.

Saba, T. M., and DiLuzio, N. R. (1968). Involvement of the ? opsonic system in starvation induced depression of the reticulo- $\overline{0}$ endothelial system. Proceedings of the Society for Experimental 3 Biology and Medicine, 128, 869.

Scrimshaw, N. S., Taylor, C. E., and Gordon, J. E. (1968). Interactions of Nutrition and Infection (Monograph Series, No. 57). World Health Organization, Geneva.

Trowell, H. C., Davies, J. N. P., and Dean, R. F. A. (1954). 을 Kwashiorkor, p. 44.. Arnold, London.

Correspondence to Dr. R. K. Chandra, Department of Paediatrics, All India Institute of Medical Sciences, $\stackrel{N}{N}$ New Delhi 16, India. 